\title{
Remuneração dos Administradores de Emprêsa: A Experiência Fiscal Brasileira Eurico Korff *
}

1. Periodo Inicial. 2. Fase de Evolução. c. Análise do Sistema Atual. 4. Procedimento de Outros Países. 5. Uma Reformulação Necessária.

\section{PERIODO INICIAL}

O regulamento aprovado pelo Decreto $n^{9} 17.390$, de 26 de julho de 1926, também conhecido como Regulamento Souza Reis e que marcou a implantação definitiva do impôsto de renda no Brasil, já estipulava na sua primeira parte, dedicada ao impôsto de renda das pessoas físicas, que "é contribuinte do impôsto sôbre a renda, da $3^{\text {a }}$ categoria, ${ }^{1}$ todo aquêle que perceber rendimentos derivados do trabalho, quer provenham do exercício de funções públicas, quer promanem do exercício das funçóes de gerentes, contadores, guarda-livros, administradores, agentes, cobradores, empregados e auxiliares do comércio ou de qualquer outra indústria, ou ainda de particulares" (artigo 10); de acôrdo com o parágrafo $1^{\circ}$ dêste artigo, letra $c$, seriam incluídos entre os contribuintes da $3^{\text {a }}$ categoria os que auferissem "bo-

* Doutor em Ciências Econômicas pela Faculdade de Ciências Econômicas de São Paulo. Diretor da Indústria e Comércio Motorit S.A.

1 Designava-se como categoria o que posteriormente seria conhecido como cédula.

R. Adm. Emp., Rio de Janeiro, 10(2): 67-95, jul./set. 1970 
nificações, gratificações, ordenados e quaisquer remunerações distribuídas aos diretores, membros dos conselhos fiscais e associados das instituições filantrópicas, sociedades anônimas e civis, quaisquer que sejam".

Referindo-se tão sòmente a "bonificações, gratificações, ordenados e quaisquer remunerações distribuídos" ou então, nos têrmos do artigo 29, simplesmente a "retiradas mensais", deixou a legislação de 1926 de fazer menção às retiradas pròpriamente pro labore. Tito Rezende, em comentário publicado em 1929, procurava demonstrar a importância de se restringir a dedutibilidade do lucro tributável àquelas retiradas "que correspondam à remuneração dos serviços prestados à sociedade ou, como se diz usualmente, que sejam retiradas pro labore, pelo trabalho", lamentando que o regulamento de 1926 "esqueceu de estabelecer expressamente essa condição" e "exigiu, apenas, que (a retirada) viesse debitada em despesas gerais"; "reclamava ainda que o regulamento, além de não conferir ao fisco condições para impugnar retiradas de sócios que não prestassem "nenhum serviço à firma" ou que até residissem no exterior, continha o "grave defeito" de "não estabelecer nenhum limite às retiradas em despesas gerais". ${ }^{2}$

Contudo, medidas legislativas anteriores que constituíram iniciativas ainda esparsas para a instituição do impôsto de renda, como os Decretos n ${ }^{\circ} 14.729$, de 1921 e 15.589, de 1922, já procuraram fixar limites, tendo o Decreto $\mathrm{n}^{\circ} 15.589$, através do seu artigo 10, parágrafo único, estabelecido expressamente que a retirada não poderia "ser superior a $12 \%$ do capital social, até o máximo de Rs.60.000\$000, anuais".

Atendendo à pretendida limitação das retiradas, o Decreto $\mathbf{n}^{\circ}$.. 21.554 veio modificar, em 1932, o artigo 29 do regulamento de 1926, dispondo que "a retirada não poderá exceder a 10:000\$000, quando o capital do respectivo beneficiário não fôr superior a 50:000\$000; sendo o seu capital maior dessa quantia, a retirada não poderá exceder a $20 \%$ dêle, jamais ultrapassando 5:000\$000 mensais". Desta maneira foi estabelecida a limitação, por sinal com o mesmo teto máximo do ano de 1922, ou seja, 60:000\$000

2 Rezende, Tito. Manual Prático do Impôsto de Renda. Rio de Janeiro, Typ. Santa Helena, 1929, p. 25 e 26. 
anuais, em conjugação, agora, com uma outra limitação, isto é, proporcional ao capital, até o nível de $20 \%$, percentagem que perduraria durante largo espaço de tempo. Outra alteração do mesmo artigo, com o evidente intuito de corrigir a omissão anterior e de cercear a dedução de retiradas não necessàriamente identificadas com a prestação efetiva de serviços, passou a restringir os rendimentos classificáveis na " 3 " categoria" da pessoa física e, portanto, dedutíveis do lucro da pessoa jurídica às "retiradas representadas por importância mensal fixa e que corresponderem à remuneração dos serviços prestados à firma ....., desde que levadas a despesas gerais, na contabilidade da firma".

O nôvo dispositivo veio ao encontro dos esfôrços da Delegacia Geral do Impôsto de Renda que, sobrepondo-se à omissão do regulamento de 1926, procurara, na prática, dificultar a dedução indiscriminada de retiradas, exigindo, tal como na decisão $n^{0} \mathbf{9 3}^{9}$, citada por Tito Rezende, que o contribuinte "prove que a retirada corresponde a remuneração pro labore; ${ }^{3}$ dêste modo, aliás, ficou restabelecido, também, o que fôra uma das condições expressas do já citado artigo $10, \S$ único, do Decreto $n^{0} 15.589$, de 1922.

A partir, portanto, do ano de 1932, a retirada dedutível passa a assumir contornos definidos, calcada nos seguintes requisitos básicos:

a) importância mensal fixa;

b) remuneração de serviço efetivamente prestado;

c) contabilização a débito da conta de despesas gerais;

d) limitação (com fixação de piso e teto, ou seja, respectivamente 10:000\$000 e 60:000\$000 anuais, e proporcional ao capital).

A estrutura seria consolidada dez anos depois, com o advento do Decreto-lei $n^{\circ} 4.178$, de 1942, ainda mais preciso: de acôrdo com o artigo $43, \S 1^{\circ}$, deveriam ser adicionadas ao lucro real "as retiradas não debitadas em despesas gerais ou contas subsidiárias, e as que, mesmo escrituradas nessas contas, não correspondam a remuneração mensal fixa por prestação de serviço" (b) e "os ordenados e percentagens pagos a membros das dire-

3 ReZende, Tito. Op. cit., p. 26. 
torias das sociedades anônimas que não residam no país" (d); o artigo $5^{\circ}$, superando a imprecisão anteriormente existente quanto à extensão da dedutibilidade aos vários tipos de pessoas jurídicas, enumera como beneficiários de retiradas expressamente os "conselheiros fiscais e de administração e diretores de sociedades anônimas e civis", os "negociantes em firma individual ou sócios de sociedades comerciais e industriais", e, finalmente, os "sócios de indústria"; não obstante a manutenção do teto anterior, houve elevação do piso para 12:000\$000 anuais, numa iniciativa destinada, decerto, a beneficiar os dirigentes das pequenas emprêsas, face ao contínuo aumento do custo de vida, naquela fase já da ordem de 7 a $12 \%$ ao ano.

Ainda num esfôrço limitador das retiradas dedutíveis, o mesmo Decreto-lei $n^{\circ} 4.178$, de 1942 , nos têrmos do artigo 43 , § $1^{\circ}$, al. 4 , veio impedir a dedutibilidade de "juros sobre o capital ou quota social atribuídos ao titular e sócios das firmas e sociedades".

Nôvo regulamento, introduzido pelo Decreto-lei $\mathrm{n}^{9} 5.844$, de 1943, manteve as determinações da legislação do ano anterior, com alguns adendos: estendendo "as remunerações relativas à prestação de serviços" pelos "conselheiros fiscais e de administração e diretores", classificáveis na cédula C (que desde 1932 substituíra a 3" categoria) a sociedade "de qualquer espécie", além das anônimas e civis (art. $5^{\circ}, \S 1^{\circ}, \mathrm{I}, \mathrm{b}$ ) e fazendo menção ao capital social "realizado" e não mais simplesmente ao capital social para a aplicação do índice de $20 \%$, relativo ao cálculo do limite de retiradas.

O próprio limite de $20 \%$, nesta altura, já vinha se constituindo numa tradição da legislação fiscal brasileira. Segundo Tito Rezende, a extensão do critério a tôdas as pessoas jurídicas resultara de uma sugestão sua, apresentada em estudo feito a pedido do Ministério da Fazenda, para reformulação dos decretos de 1926 e 1932, quando ofereceu ponderações como essas:

"atendendo a que numerosas sociedades anônimas são manejadas por um ou poucos acionistas, detentores da maioria das açóes e que assim se elegem diretores e estipulam os honorários e percentagens que muito bem entendem, mesmo absolutamente desproporcionadas às funções exercidas, 
- o que importa em deslocamento de lucros, do impôsto de $6 \%$ do art. 74 da lei atual para a taxa de $1 \%$ da cédula $\mathrm{C}$ das pessoas físicas, - seria de tôda a conveniência que, para os efeitos fiscais, houvesse uma limitação a essas remunerações..." "Proponho, pois:

a) que sejam taxados como lucros distribuídos os ordenados e percentagens pagos a membros da Diretoria que não residam no país;

b) que em quaisquer sociedades anônimas sejam também taxados como lucros os ordenados e percentagens que excedam de $20 \%$ sôbre o capital social;

c) que o excedente assim taxado seja classificado na cédula F da declaração de pessoa física dos beneficiários, distribuídos proporcionalmente a êstes"."4

Ote de 60:000\$000 (depois $\mathrm{Cr} \$ 60,00$ ), existente com interrupções desde 1922 , perdurou sem alteração até 1947 , quando a Lei $n^{\circ} 154$, refletindo afinal o recrudescimento dos índices inflacionários, no fim do período antecedente já superiores a $15 \%$ ao ano, elevou o limite máximo das retiradas para $\mathrm{Cr} \$ 120,00$ anuais, depois de aumentado em 1945 para $\operatorname{Cr} \$ 24,00$ anuais o piso de Cr $\$ 12,00$, estabelecido em 1942. ${ }^{5}$

Pela primeira vez surge, através da mesma Lei $\mathrm{n}^{\circ} 154$, de 1947, uma limitação, também, para as "gratificações", com o teto de Cr\$ 120,00 anuais, idêntico ao das retiradas; embora a lei não o definisse expressamente, coube à orientação e jurisprudência administrativas esclarecer que o dispositivo não abria nôvo tipo de remuneração aos diretores, sócios ou titulares das firmas, mas tinha o sentido específico de restringir a dedutibilidade das gratificações concedidas aos servidores assalariados das emprêsas; posteriormente, a Lei $\mathrm{n}^{\circ} \mathbf{3 . 4 7 0}$, de 1958 , eliminaria qualquer controvérsia, fazendo referência especificamente às "importâncias recebidas pelos empregados a título de gratificação".

4 Rezende, Tito. Impósto de Renda. Rio de Janeiro, 1946, p. 27.

5 Art. $5^{\circ}$ do regulamento aprovado pelo Decreto $n^{\circ} 24.320$, de 1947; o aumento, em 1945, resultara do Decreto-lei $n^{\circ} 8.430$.

6 Art. $5^{\circ}$ do regulamento aprovado pelo Decreto $n^{\circ} 47.373$, de 1959.

Julho/Setembro 1970 
A Lei $n^{\circ} 1.474$, de 1951 , elevou o piso de $\operatorname{Cr} \$ 24,00$ para $\mathrm{Cr} \$ 30,00$ anuais, que assim figura no regulamento aprovado pelo Decreto $\mathrm{n}^{\circ} 36.773$, de 1955 , onde o teto permanece na mesma base de Cr\$ 120,00 anuais de 1947.

A longa imobilidade dos tetos, não obstante a existência de índices de aumento de preços entre 15 e $30 \%$ ao ano já na década de 1950 , conduziu a constantes tentativas para a superação da barreira, inclusive de forma indireta, como, por exemplo, através do expediente das despesas de representação de dirigentes de emprêsa, entretanto sistemàticamente repelido pela jurisprudência administrativa. ${ }^{7}$ Por outro lado, fisco e tribunais administrativos persistiram em constante zêlo pela prestação efetiva de serviços a justificar as retiradas, declarando que "não se admitem honorários a diretores que não lhes prestem serviços" - "as deduções permitidas às pessoas jurídicas são as despesas que se relacionam com a atividade exploradora e indispensáveis à realização do lucro"' ou "simples 'atenção dispensada à firma por um sócio' não corresponde a prestação de serviços, não se justificando, por isso, o pagamento de remuneração pro labore". ${ }^{9}$ A vigilância se estendeu, também, a empregados transformados em sócios ou diretores, sem extinção do vínculo empregatício; enquanto a remuneração habitual dos servidores das emprêsas não sofre qualquer restrição fiscal, salvo a já referida limitação das gratificações, passa o fisco a submetê-los, uma vez convertidos em sócios ou diretores, aos mesmos limites de retiradas dedutíveis dos dirigentes não-empregados; assim, de acôrdo com várias decisões, "incide na limitação a remuneração do sócio que, para efeito das leis trabalhistas conserva a sua condição de empregado", 10 o mesmo acontecendo "em relação aos sócios-cotistas que exercem funções de operários ou empregados da emprêsa", t1 e "não importa que provado fique o contrato de trabalho da sociedade com os seus diretores, por isso que a tributação dos excessos tem como obje-

\footnotetext{
7 Ver, por exemplo, Decisão $n^{\circ} 25$ do $1^{\circ}$ Conselho de Contribuintes. In Revista Fiscal, 1953.

8 Decisão $\mathrm{n}^{\circ} 308$ do $1^{0}$ Cons. Contribuintes. In Revista Fiscal, 1954.

9 Decisão $n^{\circ} 487$ do $1^{*}$ Cons. Contribuintes. In Revista Fiscal, 1952.

10 Decisão $n^{\circ} 626$ do $1^{\circ}$ Cons. Contribuintes. In Revista Fiscal, 1952.

11. Decisão $n^{\circ} 459$ do $1^{\circ}$ Cons. Contribuintes. In Revista Fiscal, 1952.
} 
tivo evitar o perigo de fraude contra a Fazenda Nacional, criando, assim, uma regra peculiar ao tributo em causa, afastando-se ou contrariando mesmo o direito comum, o que aliás é admitido pela moderna orientação jurídica, no tocante à autonomia do direito tributário", 12 como também não importa "que os serviços prestados pelos diretores o foram em setor estranho ao de suas obrigações". ${ }^{13}$

O regulamento de 1956 , aprovado pelo Decreto $n^{\circ} 40.702$, e que incorporou os dispositivos das Leis $\mathrm{n}^{\circ} 2.862$ e 2.973 do mesmo ano, ainda traz a manutenção do teto de $\mathrm{Cr} \$ 120,00$ anuais, embora com o piso aumentado para $\mathrm{Cr} \$ 60,00$ anuais, desta forma ao menos beneficiando os dirigentes das emprêsas menores.

\section{Fase de Evolução}

Coube, finalmente, à Lei $\mathrm{n}^{\mathrm{o}} 3.470$, de 1958, acabar com o teto fixo, tão longamente conservado; substituiu-o, nos têrmos do seu artigo 42, pelo limite máximo móvel, correspondente a quatro vêzes o salário mínimo mensal de maior valor (restrito aos três primeiros beneficiários e reduzido a três vêzes êsse salário para os demais, respeitado também um teto coletivo, agora criado, de 28 vêzes o mesmo salário mínimo mensal para a totalidade dos diretores e sócios de cada pessoa jurídica). A medida traduziu-se na elevação efetiva e imediata do teto de $\mathrm{Cr} \$$. . 120,00 para $\mathrm{Cr} \$ 182,40$, ao final do ano de 1958; característica móvel foi conferida, igualmente, ao piso, ao nível de $50 \%$ do teto, passando, portanto, de $\mathrm{Cr} \$ 60,00$ a $\mathrm{Cr} \$ 91,20$ anuais. Entre piso e teto houve ainda a introdução de duas faixas intermediárias, relativas às firmas e sociedades com capital realizado superior a $\operatorname{Cr} \$ 2.000,00$ e não excedente a $\operatorname{Cr} \$ 3.000,00$, e aquelas com capital realizado superior a $\mathrm{Cr} \$ 3.000,00$ e não excedente a $\mathrm{Cr} \$ 5.000,00$, cujos sócios ou diretores passaram a fazer jus a, respectivamente, $60 \%$ e $80 \%$ do teto. Foram excluídos dessas restrições os dirigentes de firmas ou sociedades cuja receita fôsse constituída em mais de $80 \%$ de "rendimentos oriundos de serviços profissionais ou de assistência técnica administrativa",

12 Decisão $n^{\circ} 173$ do $1^{\circ}$ Cons. Contribuintes. In Revista Fiscal, 1954.

13 Decisão $n^{\circ} 151$ do $1^{\circ}$ Cons. Contribuintes. In Revista Fiscal, 1953.

Julho/Setembro 1970 
cuja remuneração poderia atingir os limites máximos, independentemente do seu capital.

A inovação do teto móvel beneficiou, além dos "negociantes em firma individual" e "sócios das emprêsas comerciais e industriais", apenas os "diretores de sociedades anônimas, civis ou de qualquer espécie", sem estender-se aos conselheiros fiscais e de administração, não mencionados pela Lei $\mathrm{n}^{\circ} 3.470$ e limitados em virtude de disposição anterior ${ }^{14}$ ao teto de $20 \%$ do capital social realizado ou de $\mathrm{Cr} \$ 60,00$ anuais fixos. O regulamento seguinte, aprovado pelo Decreto $n^{\circ} 47.373$, de 1959, atende a êsse tratamento diversificado, classificando em itens separados os diretores, de um lado, e os conselheiros, de outro, norma desde então seguida, quando antes foram agrupados num só item, embora com limites diferentes. Concedendo, outrossim, status fiscal definido aos "representantes no Brasil de firmas ou sociedades estrangeiras autorizadas a funcionar no território nacional", autorizou a Lei $\mathrm{n}^{\circ} 3.470$, de 1958 , através do seu artigo 45, a sua equiparação aos "diretores de sociedades anônimas", "para os efeitos de tributação".

Por força do artigo 43 da mesma Lei $n^{\circ} 3.470$, o princípio do teto móvel foi estendido também às "importâncias recebidas pelos empregados a título de gratificação", limitado a "três vêzes o valor do maior salário mínimo anual vigente no país para cada um dos beneficiários", significando, na prática, uma elevação imediata do teto de $\mathrm{Cr} \$ 120,00$ para $\operatorname{Cr} \$ 212,40$.

Conferida flexibilidade ao teto das retiradas de 1958 , limitado respectivamente a 4 ou 3 salários mínimos mensais, seria a concessão ampliada em 1962, por determinação da Lei $\mathrm{n}^{\circ} 4.154$ (art. 22), para 6 vêzes o agora chamado salário mínimo fiscal, até o número de 3 beneficiários, e a 5 vêzes êsse salário para os demais, mantidos, porém, o teto coletivo de 28 vêzes o salário mínimo e a redução a $50 \%, 60 \%$ e $80 \%$ para piso e faixas intermediárias, o que se exprimiu no estabelecimento, na ocasião, de um teto anual de $\mathrm{Cr} \$ 1.008,00$ e um piso de $\mathrm{Cr} \$ 504,00$.

$O$ ano de 1964 , com o advento da Lei $n^{\circ} 4.506$, trouxe o abandono do salário mínimo como ponto de referência; assim os va-

14 Lei $n^{\circ} 154$, art. $1^{\circ}$. 
lôres até então expressos em salários mínimos seriam "convertidos em cruzeiros", sujeitando-se, a seu turno, "os valôres expressos em cruzeiros na legislação do impôsto de renda" a atualização periódica "em função de coeficientes de correção monetária estabelecidos pelo C.N.E., desde que os índices gerais de preços se elevem acima de $10 \%$ ao ano ou de $15 \%$ em um triênio" (art. $3^{\circ}$ ). Nestas circunstâncias foi instituído o nôvo teto de $\operatorname{Cr} \$ 12.000,00$ anuais e um piso de $\operatorname{Cr} \$ 2.400,00$ anuais, com três faixas intermediárias, correspondentes a 30,40 e $60 \%$ do teto; ${ }^{15}$ êsses limites foram atribuídos especificamente à "remuneração dos sócios-gerentes, diretores ou administradores, individual ou colegialmente considerados, de sociedades comerciais ou civis de qualquer espécie, assim como negociantes em firma individual", sendo a remuneração de "cada um dos conselheiros fiscais ou consultivos de sociedades comerciais, civis ou de qualquer espécie limitada a $\mathrm{Cr} \$ 500,00$ anuais. $O$ teto coletivo foi substituído pela limitação do número de "diretores ou gerentes" com retirada dedutível a três - para firmas ou sociedades de capital inferior a $\mathrm{Cr} \$ 50.000,00$, quatro, de capital superior a $\operatorname{Cr} \$ 50.000,00$ e inferior a $\operatorname{Cr} \$ 100.000,00$, e sete, de capital superior a $\operatorname{Cr} \$ 100.000,00$ (art. 51).

Ao lado dessa reformulação da retirada dos dirigentes, salienta-se a lei de 1964, pelo empenho de cercear o desvirtuamento, procurando enfrentar alguns dos riscos lembrados por Tito Rezende no início da década de 1930, em comentários já citados, e que, ao longo dos anos, nunca deixaram de ser alvo da vigilância das autoridades e tribunais administrativos. Neste sentido merece destaque o poder agora conferido expressamente à "administração do impôsto" para impugnar "os pagamentos de qualquer natureza" feitos não só a "titular, sócio ou dirigente de emprêsa" como até a "parente dos mesmos", desde que o contribuinte não prove, "no caso de compensação por trabalho assalariado, autônomo ou profissional, a prestação efetiva dos serviços" e "no caso de outros rendimentos ou pagamentos, a origem e a efetividade da operação ou transação", incluídas entre êsses pagamentos "as despesas feitas direta ou indireta-

15 Faixas delimitadas pelo capital social, isto e, respectivamente, .... Cr $\$ 25.000,00$ a $\operatorname{Cr} \$ 50.000,00, \operatorname{Cr} \$ 50.000,00$ a $\operatorname{Cr} \$ 500.000,00$ e superiores a $\operatorname{Cr} \$ 500.000,00$. 
mente, pelas emprêsas, com viagens para o exterior, equiparando-se os gerentes a dirigentes de firma ou sociedade" (art. 47, $\S 5^{\circ}$ e $7^{\circ}$ ). No caso da "emprêsa individual", autoriza-se a "administração do impôsto" a "impugnar as despesas pessoais do titular da emprêsa que não forem expressamente previstas na lei como deduções admitidas, se êsse não puder provar a relação da despesa com a atividade da emprêsa" (art. 47, § $4^{\circ}$ ). É estabelecido expressamente, também, que "não serão dedutíveis como despesas operacionais" as gratificações ou participações no resultado, atribuídas aos dirigentes ou administradores de pessoa jurídica" (art. $45, \S 3^{\circ}$ ), cuja "remuneração dedutível" ficou evidentemente limitada às bases estipuladas no artigo 51, acima referido. Reiterando, por sua vez, disposição contida no já citado Decreto-lei $\mathrm{n}^{\circ} 4.178$, de 1942 , confirma a Lei $n^{\circ} 4.506$, de 1964, que "não serão admitidos como custos ou despesas operacionais as importâncias creditadas ao titular ou aos sócios da emprêsa, a título de juros sôbre o capital social", abrindo exceção apenas para os associados de cooperativas (art. 49). Além da capacidade de efetuar tôdas essas impugnações, recebeu o fisco ainda podêres para considerar, entre outras, como "formas de distribuição disfarçada de lucros ou de dividendos" "o pagamento de remuneração por trabalho assalariado, autônomo ou profissional, que não corresponda a serviços efetivamente prestados" e "o pagamento de despesas particulares" de "acionistas, sócios, diretores ou participantes nos lucros de pessoa jurídica" ou "aos respectivos parentes ou dependentes", "salvo quando satisfazerem as condições legais para serem classificados como rendimento do trabalho autônomo ou profissional" (Art. 72 - III e V).

Entre tantos dispositivos de agravamento fiscal, surgiu, contudo, a concessão há tanto tempo reclamada, de dedutibilidade das "despesas de representação"; efetivamente, a partir da Lei $n^{\circ} 4.506$, e em decorrencia do que determinava o seu artigo 18 , alínea IX, passou-se a admitir essas despesas, quando "pagas por entidades privadas a seus dirigentes ou administradores, ou a empregados cujas atribuições imponham gastos desta natureza, desde que compreendidas no limite de $15 \%$ da remuneração mensal devida, o que significou, de imediato, acrescer, a êsse título, mais $15 \%$ às retiradas dedutíveis. 
Para que se justifique a dedutibilidade dos vencimentos atribuidos ao dirigente, é mister que a atividade se enquadre dentro do "conceito de administrador", conforme a Instrução Normativa $\mathrm{n}^{\circ}$ 2, de 12/9/1969, da Secretaria da Receita Federal: "é a pessoa que pratica, com habitualidade, atos privativos de gerência ou administração de negócios da emprêsa, e o faz por delegação ou designação de assembléia, de diretoria ou de diretor".

Coube ao Decreto-lei $\mathrm{n}^{0} 401$, de 30 de dezembro de 1968, modificar mais uma vez e de forma substancial o tratamento fiscal da "remuneração dos sócios, diretores ou administradores de sociedades comerciais ou civis, de qualquer espécie, assim como a dos titulares das emprêsas individuais", nos têrmos do seu artigo 16, o qual constitui o dispositivo que, atualmente, regula a matéria, com as modificações que lhe foram introduzidas pelo Decreto-lei $n^{0} 1.089$, de 2/3/1970.

Assim como a Lei $\mathrm{n}^{0} 4.506$, em 1964, trocara o salário mínimo, como elemento de cálculo dos limites de retirada, por "valôres expressos em cruzeiros", reajustáveis periòdicamente, êsses valôres, corrigidos nos anos-bases de 1965, 1966 e 1967, ${ }^{16}$ foram substituídos pelo Decreto-lei n' 401 por um nôvo ponto de referência: "o valor fixado como mínimo de isenção na tabela do desconto do impôsto na fonte sôbre rendimentos do trabalho assalariado"; desta maneira, foi estabelecido bàsicamente como piso o próprio valor do mínimo de isenção ( $\mathrm{Cr} \$ 580,00$ mensais no ano-base de 1968 e $\mathrm{Cr} \$ 696,00$ no de 1969) e como teto o equivalente a 5 vêzes êsse valor no ano-base de $1968(\mathrm{Cr} \$$.. $2.900,00$ mensais), elevado a 7 vêzes a partir do ano-base de 1969 (Cr\$ 4.872,00 mensais) por fôrça do citado Decreto-lei $\mathrm{n}^{\circ}$ 1.089, o qual, todavia, extinguiu a dedutibilidade das despesas de representação.

O limite colegial de sete dirigentes, a fazerem jus a retiradas dedutíveis, que no regime da lei de 1964 estivera reservado às sociedades com capital superior a $\mathrm{Cr} \$ 100.000,00$ (sendo reduzi$\sqrt{6}$

16 Corrigidos os tetos para respectivamente $\operatorname{Cr} \$ 15.120,00, \operatorname{Cr} \$ 21.470,00$ e $\operatorname{Cr} \$ 26.196,00$ anuais, e os pisos para $\operatorname{Cr} \$ 3.024,00, \operatorname{Cr} \$ 4.294,08 \mathrm{e}$ Cr\$5.244,00 anuais para os anos-base de 1965, 1966 e 1967. 
do para as de menor capital), passou a ter a sua aplicação isenta de restrição de capital.

Se essas inovações do Decreto-lei $n^{\circ} 401$, dada a melhoria que representaram para 0 contribuinte, foram bem acolhidas, 0 mesmo não sucedeu com o parágrafo $1^{\circ}$ do seu artigo 16 que, limitando a dedutibilidade das "remunerações pagas na forma dêste artigo" a até $30 \%$ do lucro tributável, antes de feita a dedução dessas mesmas remunerações", abriu, por assim dizer, uma terceira fase no tratamento fiscal dêsses vencimentos, cuja evolução, já analisada em pormenores, pode ser assim resumida:

$1^{\text {s }}$ fase: 1922-1957 - teto expresso em valor fixo, conjugado com limite, a princípio de $12 \%$, posteriormente de $20 \%$ do capital;

$2^{\text {a }}$ fase: 1958-1967 - teto variável, baseado no salário mínimo, posteriormente em valôres reajustáveis expressos em cruzeiros, com a fixação do limite máximo e dos das faixas intermediárias, baseada no capital;

$3^{\text {a fase: }} 1968$ - teto variável, baseado em mínimos de isenção, conjugado com limitação a $30 \%$ do lucro tributável.

\section{Análise do Sistema Atual}

Substituído o teto da primeira fase, expresso em valor fixo, insustentável a longo prazo em atmosfera inflacionária, deveria o teto móvel da segunda e terceira fases permitir o ajustamento periódico das remunerações dedutíveis dos administradores aos índices de aumento do custo de vida.

Pode merecer reparos - e será analisado mais adiante o ponto de partida para a aplicação dos posteriores reajustes, isto é, se é razoável a limitação básica a quatro ou seis vêzes o salário mínimo (ou variantes), ou cinco ou sete vêzes o mínimo de isenção; estabelecidos, porém, êsses limites iniciais, seria lícito esperar que a remuneração dos dirigentes, em princípio, se mantivesse estável em têrmos reais, paralelamente, tanto quanto possivel, à dos demais auxiliares da emprêsa. A adoção do salá- 
rio mínimo, com a variante posterior dos "valôres expressos em cruzeiros", ambos com os respectivos reajustes, ofereceu condições para que tal continuidade ocorresse, a primeira modalidade (do salário mínimo) mais em relação às remunerações dos demais colaboradores da emprêsa, a segunda (dos "valôres expressos em cruzeiros") mais em relação ao índice geral dos preços; já a utilização dos limites mínimos de isenção, só teria òbviamente o mesmo efeito se obedecesse sempre aos princípios de correção monetária periódica e não a eventuais outros interêsses como, por exemplo, o de incremento da arrecadação. Seria esta uma das restrições de ordem teórica à nova disposição, porém não a mais importante.

$\mathrm{Na}$ primeira e segunda fase funcionou como elemento moderador ou redutor o capital de pessoa jurídica, servindo de ponto de referência para a contenção das retiradas dedutíveis aquém dos limites máximos. A introdução dêste elemento proporcionou, na prática, o escalonamento de limites em função da grandeza das pessoas jurídicas, com a existência de situações intermediárias entre teto e piso, êste último sempre concedido sem dependência do capital. A remuneração dedutível do dirigente, estabelecida como múltiplo do salário mínimo ou correspondendo aos "valôres expressos em cruzeiros", manteria paralelismo razoàvelmente contínuo em relação aos demais níveis de remuneração da emprêsa, como retribuição, ela também, do fator trabalho. A inserção do capital não se processava, aqui, como fator a ser, também, remunerado, mas simplesmente para o fim de graduação do honorário do dirigente. Apenas o crescimento da própria emprêsa, expresso no aumento do seu capital, teria condições para incrementar, em têrmos reais, o nível de remuneração dedutível do dirigente da emprêsa dos escalões intermediários, isto é, a partir do piso até alcançar o teto, que contudo não poderia ser ultrapassado. Ressalvada a possível insuficiência do ponto de partida e a prolongada contenção dos níveis de capital, hoje, ao menos em parte, corrigida em relação ao capital fixo e, também, com referência ao circulante, demonstrou o sistema condições para assegurar, em têrmos reais, a continuidade da remuneração dos dirigentes e, dentro de certos limites, até a sua melhoria, de acôrdo com a expansão das emprêsas dirigidas. 
A preocupação de estimar o valor do trabalho prestado pelo dirigente, que caracterizou o período 1958-1967, expressa na sua vinculação com a remuneração mínima do trabalho assalariado, cedeu com a nova fase, inaugurada pelo Decreto-lei $n^{\circ} 401$, de 1968 , sobretudo ao relacionamento da retirada com - lucro apurado pela pessoa jurídica pagadora, não obstante, à primeira vista, o mínimo de isenção (e seus múltiplos) se destinar a suprir o papel anteriormente desempenhado pelo salário mínimo ou pela variante dos "valôres expressos em cruzeiros"; tanto isto sucede que a retirada do diretor de uma sociedade, fixada no início do ano de 1968 em cinco vêzes o mínimo de isenção, ou seja, $\operatorname{Cr} \$ 34.800,00$ anuais, teria de ser reduzida para o piso de $\mathrm{Cr} \$ 6.960,00$ anuais, se a sociedade ao fim do exercício não apresentasse lucro. Chega-se, por conseguinte, à conclusão de que sòmente existe garantia do piso e que todo o excedente a êsse valor depende dos resultados da emprêsa, passando a constituir uma remuneração variável, insuscetível como tal de determinação prévia e mensal.

Sem embargo de haverem surgido observações como a de Fábio Fanucchi, considerando-o "bem mais racional", ${ }^{17}$ o nôvo critério parece questionável, enquanto pretende fazer do lucro da emprêsa, essencialmente remuneração do capital de risco, base também para a remuneração do fator trabalho. ${ }^{18}$

Em épocas anteriores, principalmente antes dos aumentos da remuneração dedutível em têrmos reais, obtidos notadamente em 1958, 1962 e 1964, as autoridades fazendárias tinham por hábito justificar os tetos baixos das remunerações, com a alegação de que os dirigentes, dada sua condição, também, de sócios ou acionistas, seriam compensados pela sua participação nos lucros das emprêsas; o nôvo critério parece institucionalizar êsse ponto de vista.

Que dizer, entretanto, do constante zêlo dessas mesmas autoridades, destacado por várias vêzes neste trabalho, para vincular as retiradas ao trabalho efetivamente prestado, formulan-

17 FANUCCHI, Fábio. Estudo sôbre os Decretos-leis no 401 e 403. São Paulo, Ed. Resenha Tributária, 1969, p. 20.

18 Embora aqui, dado o já mencionado impedimento fiscal de consideração do juro do capital, se confundam as noçóes de juro - do capital - e do lucro pròpriamente dito, êste, em teoria, remuneração do empreendimento. 
do, inclusive, uma série de condições expressas para assegurar que a retribuição seja realmente pro labore? Que dizer, também, da prévia determinação de retiradas mensais e fixas, sempre exigida e agora virtualmente impossibilitada, face à natural imprevisibilidade de resultados?

O resultado econômico de um empreendimento é afinal fruto da conjugação de vários fatôres (um dêles e não o único - o trabalho dos dirigentes) e de uma série de circunstâncias (por vêzes totalmente imprevistas, como por exemplo, uma importação especialmente bem sucedida devido à evolução da situação cambial, um lançamento imobiliário bafejado pela valorização de tôda uma área decorrente da inesperada abertura de novas vias de acesso etc.); assim como outros fatôres ou circunstâncias, além do trabalho pessoal dos dirigentes, podem produzir resultados mais favoraveis, também poderão conduzir a resultados inferiores ou negativos, não obstante o esfôrço constante dos administradores. Não só não parece ser dos mais equitativos um critério que só reconhece o esfôrço em presença do êxito, como também lhe faltam condiçóes para garantir o fisco contra o desvirtuamento da retirada, substituindo as condiçóes até agora impostas para cercear o pagamento de retiradas aos que não prestam serviços efetivos; muito pelo contrário, quanto maior o lucro, maior a tendência para o aumento do número de diretores, com a possibilidade de maior absorção do lucro tributável. Pela sua natureza aleatória, enfim, não se presta o lucro para substituir o capital como elemento qualificado para aferir a grandeza do empreendimento.

O fisco, tradicionalmente, só tem admitido como dedutíveis as retiradas estabelecidas em assembléias ou contratos durante 0 exercício e, portanto, fixas e mensais, sem aceitar sua complementação no fim do exercício, não obstante elevação dos próprios tetos fiscais, retroativa em relação ao ano-base. ${ }^{19}$ No regime anterior, fixada uma retirada no início do ano, com observância dos tetos existentes, via-se o contribuinte compelido pelo fisco a respeitar essa retirada, sem beneficiar-se dos tetos reajustados que só aproveitariam àqueles que por antecipação

19 Ver Fanucchi, Fábio. Impósto de Renda das Empresas. Săo Paulo, Editora Resenha Tributária, 1968, p. 74. 
tivessem estabelecido retiradas superiores aos tetos iniciais, sujeitando-se à eventual não dedutibilidade dos excessos. Tendo sempre obrigado o contribuinte a respeitar as retiradas fixadas no início, não lhe permitindo aumentá-las no fim do exercício comercial, passaria o fisco, de sua parte, a não respeitar essas retiradas, tanto que ao fim do exercício pode vir a reduzir a sua dedutibilidade. Enquanto que, no regime anterior, a emprê$\mathrm{sa}$, desde que remunerasse os seus dirigentes até os vários tetos, estabelecidos de acôrdo com o capital, nenhum risco assumia, na presente situação constitui risco qualquer remuneração que exceda o piso; por outro lado, prevalecendo ainda a restrição anterior a impedir uma complementação no fim do exercício, os que em ata ou contrato; temendo o risco, se limitam a fixar retiradas equivalentes ao piso perdem a oportunidade de, posteriormente, reajustarem as retiradas.

Consequêencias ainda mais senșíveis surgem para as emprêsas deficitárias.

E bem ilustrativo o exemplo de importante firma industrial e comercial do setor de modas femininas, com sede em São Paulo e ramificações em todo o País, de cujas publicações obrigatórias podem ser extraídos os seguintes dados:

Capital realizado

Cr\$ $1.150 .000,00$

Prejuízo do ano-base (1967)

$\mathrm{Cr} \$$

$34.459,10$

Número de diretores

Pelo sistema do periodo 1957-1967, vigente no exercício de 1968 , a sociedade, tendo capital superior a $\operatorname{Cr} \$ 1.091 .412,00$ e náo excedente a $\operatorname{Cr} \$ 2.182 .824,00$, poderia, de acôrdo com a ordem de serviço $n^{\circ}$ DIR-11/67, manter até sete diretores com o honorário anual de Cr\$ $15.720,00$ cada; assim sendo,

mantendo 5 diretores $x \operatorname{Cr} \$ 15.720,00$

$\mathrm{Cr} \$ 78.600,00$ tributação adicional nihil

Pelo sistema do Decreto-lei 401, de 1968, enfrentaria a seguinte situação:20

20 Por ser desconhecido e faita abstraçăo do imposto do renda pago em 1967, referente ao ano-base de 1966 . 
Efetivamente pago, conforme legislação do sistema anterior

$\mathrm{Cr} \$ \quad 78.600,00$

Redução da remuneração para o piso, conforme art. $16, \S 2^{\circ}: 5 \times 5.960,00$ anuais

Cr $\$ 29.800,00$

Excesso de retiradas

Cr\$ $48.800,00$

Prejuízo do ano-base

Cr\$ $34.459,10$

Lucro tributável

Cr\$ $14.340,90$

Tributação sôbre lucro, inclusive distribuição $(30+5=35 \%)$

$\mathrm{Cr} \$ \quad 5.019,31$

Havendo um prejuízo efetivo de

Cr\$ $34.459,10$ com a necessidade de tributação de parte das retiradas

$\mathrm{Cr} \$ \quad 5.019,31$

verifica-se um aumento do prejuízo para

Cr\$ $39.478,41$

Quando o prejuízo efetivo deixa de transformar-se em lucro tributável, isto é, quando é de tal vulto que cobre qualquer excesso de retiradas, como foi, por exemplo, o caso de grande indústria de produtos eletrônicos, também sediada em São Paulo, que apresentou no ano-base de 1968 um prejuízo de,

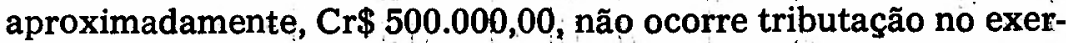
cício de 1969; se, entretanto, a mesma emprêsa, superando a fase menos feliz, puder obter resultados positivos nos anos seguintes, também sentirá o reflexo, em virtude de se haver reduzido o prejuizo sob o ponto de vista fiscal, suscetível de ser absorvido pelos lucros futuros; neste caso, embora de forma mais remota do que no primeiro exemplo, o dispositivo não deixa de punir ainda mais os que já sofrem os efeitos de resultados negativos.

As firmas que terminaram o ano-base de 1968, com resultados positivos, tendo no início do ano fixado as remunerações dos seus dirigentes com base na legislação então vigente (do período 1957-1967), defrontaram-se com a seguinte situação, ao apresentarem sua declaração de rendimentos de acốrdo com o nôvo sistema, introduzido no fim do ano-base:at :

21 Hipotese adotada: relaçăo lucro tribuțável/capital $=20 \%$; entre parênteses ( ) figura o número de dirigentes. 


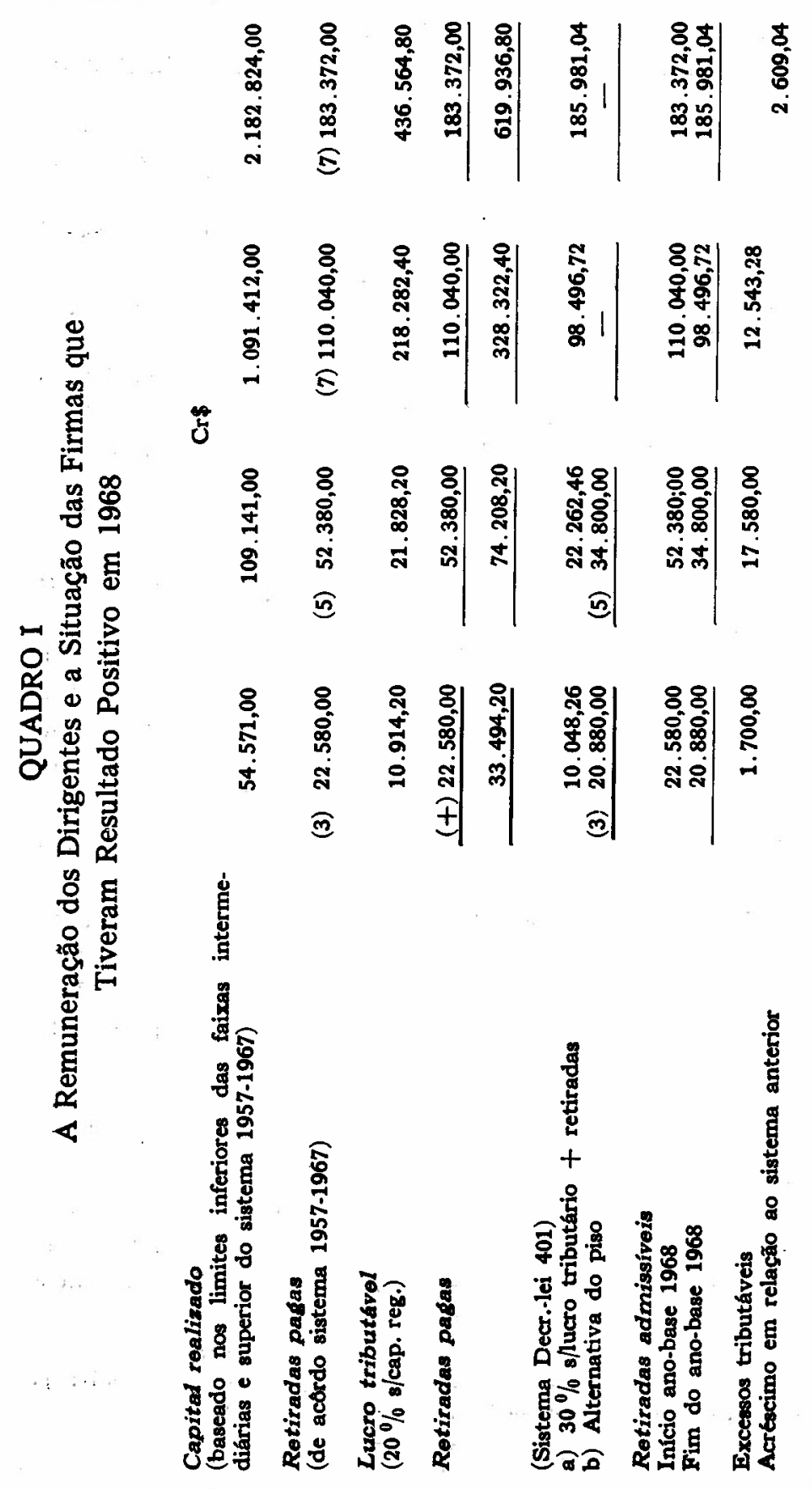


Nota-se que o critério lucro é mais desvantajoso para os escalóes inferior e médio, mais para êsse último, por ser menos favorecido pela interferência moderadora do piso que, na faixa inferior, consegue anular a influência negativa do critério lucro. Observa-se, mesmo, no terceiro escalão ainda a permanência da ação desfavorável do critério lucro, invertendo-se a situação sòmente a partir da última faixa, acima do limite superior

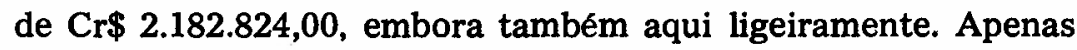
à medida que aumentem os lucros tributáveis nessa faixa superior, o nôvo sistema oferece maiores benefícios às emprêsas enquadráveis até se alcançar o teto absoluto constituído pelo teto colegial de retiradas.

O teto colegial de $\operatorname{Cr} \$ 243.600,00$, correspondente à retirada individual de $\mathrm{Cr} \$ 34.800,00$ anuais ou de $\mathrm{Cr} \$ 2.900,00$ mensais, seria alcançado como produto de um capital realizado de $\mathrm{Cr} \$ 2.842 .000,00$ ou de $\mathrm{Cr} \$ 3.789 .300,00$, considerada, respectivamente, uma rentabilidade de $20 \%$ ou $15 \%$ sôbre o capital registrado.

Enquanto a faixa superior pôde proporcionar ao dirigente uma retirada mensal de Cr $\$ 2.900,00$, ou seja, cêrca de 22 salários mínimos, a primeira e segunda faixas (intermediárias) limitariam a retirada a $\mathrm{Cr} \$ 580,00$ mensais, ou seja, cêrca de 4,4 salários mínimos, alcançando no terceiro escalão $\mathrm{Cr} \$ 1.200,00$ mensais, ou aproximadamente 9,3 salários mínimos. Conforme informações existentes sôbre o mesmo período, a remuneração de colaboradores assalariados, de nível gerencial ou técnico com qualificações e preparo especializados, variariam em tôrno de 15 salários mínimos mensais, a partir de empregadores de porte médio.

Quanto à localização dos exemplos elaborados nos limites inferiores das faixas estabelecidas no sistema anterior, não resta dúvida de que, à medida em que houvesse sucessivo deslocamento em direção aos limites superiores das faixas, o capital mais volumoso tenderia a ensejar melhores lucros e, em consequiência, retiradas mais favoráveis; além de menos aproveitar 
as empresas, quanto mais se aproximassem dos limites inferiores, tal deslocamento, obviamente, apenas beneficiaria as demais se mantida a rentabilidade hipotética de $20 \%$; mesmo essa rentabilidade, dadas as condições do período, com notória pressão de custos, sobretudo de ordem financeira, como resultado da insuficiência de recursos próprios, freqüentemente não se verificaria, contribuindo para que as hipóteses aventadas pudessem até ser julgadas otimistas; ${ }^{22}$ a extensão do limite colegial a sete diretores para tôdas as sociedades não teria, por sua vez, maior significação para as emprêsas médias e pequenas.

A relação retirada/salário mínimo, melhorada em 1962 e 1964, correspondendo em 1967, respectivamente, o teto e piso a cêrca de 20 e 4 salários mínimos, vinha, não obstante as melhorias já verificadas, merecendo sérios reparos, principalmente a respeito da remuneração dos dirigentes de emprêsas dos escalóes intermediários, limitada a aproximadamente 6,5 a 10 salários mínimos, notỏriamente inferior em relação aos colaboradores assalariados.

O nôvo sistema do Decreto-lei $n^{\circ} 401$, elevando o teto de cêrca de 20 para 22 e posteriormente 31 salários mínimos, trouxe, aparentemente, a melhoria reclamada para as demais faixas que, face à supressão de limites intermediários, poderiam, em teoria, alcançar retiradas equivalentes ao teto de aproximadamente 22 ou 31 salários mínimos; é a inserção do critério lucro, nas condições em que aconteceu, que, tal como foi demonstrado, tirou, na prática, a numerosas emprêsas a oportunidade de utilizar a vantagem ou até as inferiorizou no tocante à situação anterior.

Ao longo dos últimos anos tem a vigilância do fisco sôbre a conservação dentro das emprêsas dos lucros oficialmente suspensos recebido o apoio de vários dispositivos, tais como o artigo $9^{9}$ da Lei $n^{\circ} 4.154$, de 1962 , que passou a considerar lucro distribuído da pessoa jurídica as retiradas feitas por sócios,

22 Segundo declaraçóes prestadas pelo titular da Fazenda "não e tão comum" atingir-se "um lucro líquido de 20\%" (O Estudo de São Paulo, $30 / 11 / 1969$, p. 6 ). 
acionistaś, seus cônjuges e dependentes, a títulò de empréstimo, desde que não cumprida certas restriçóes, e os artigos 72 e 73 da Lei n 4.506, de 1964, relativos à "distribuição disfarçada de lucros", sendo o esquema indiretamente reforçado com a obrigatoriedade de declaração anual de bens das pessoas físicas, conforme o artigo 51 da Lei $n^{\circ}$ 4.069, de 1962.

Essa vigilância alcançaria ainda maior eficiência e justificação se o seu rigor se conjugasse com um critério mais liberal e mesmo mais objetivo para a fixação dos honorários de diretores, a fim de que se lhes ofereçam condições mais convidativas para efetuarem abertamente tôdas as suas retiradas e se deixe de provocar adiantamentos em conta corrente, de caixa ou outros expedientes ainda menos justificáveis. $A$ análise aqui feita não indica haver sido encontrada a fórmula mais adequada para oferecer tais condições.

\section{Procedimento de Outros Países}

George Thomas Washington e V. Henry Rotschild, em extenso estudo sôbre a remuneração do corporate executive nos Estados Unidos da América, salientam como característica principal da posição fiscal norte-americana a flexibilidade, baseada na razoabilidade do volume de remuneração e no grau de identificação do beneficiário (ou de seu parentesco) com o ou os controladores da emprêsa, pressuposta sempre a natureza útil e necessária da despesa.

Quando pode ter a convicção de não existir tal identificação ou parentesco e quando a determinação do honorário é fruto de decisões de assembléias constituídas por grande número de acionistas, sem dominio por parte da administração, o fisco norte-americano tende a dispensar melhor acolhimento aos níveis estabelecidos. Em consequêencia, a atenção das autoridades fazendárias se concentra mais sôbre as sociedades fechadas, procurando distinguir entre a legítima compensação por serviço efetivamente prestado e a distribuição disfarçada de lúcros ou um donativo oculto, já que na ausência de oposição de interêsses entre acionistas e diretoria prevaleceria a tendência de distribuir a maior parte do lucro como remuneração da dire-

Julho/Setembro 1970 
toria... No exame das controvérsias, freqüentemente levadas até o Judiciário, têm os tribunais estadunidenses recorrido essencialmente à análise de quatro aspectos: o volume do negócio ao qual o dirigente se acha ligado, a finalidade e as responsabilidades do seu trabalho, as suas qualificaçóes e contribuições para o sucesso do empreendimento e as remuneraçס̃es pagas para funçóes comparáveis em atividades comparáveis. ${ }^{23}$

$\mathrm{Na}$ Grã-Bretanha a legislação do profits tax restringe a dedução como despesas dos pagamentos feitos a diretores que controlam a sociedade ou a qualquer pessoa que possua $20 \%$ ou mais de ações ordinárias, excluídos de antemão os chamados whole time service directors, ou seja, os que dediquem o seu tempo integral à sociedade numa função administrativa ou técnica e não controlem, individualmente, mais de $\mathbf{5 \%}$ do seu capital acionário ordinário. ${ }^{24}$

$\mathrm{Na}$ França, além de indagações em tôrno da identificação (e do parentesco) do diretor com o grupo controlador, prevalece também a flexibilidade quanto aos níveis propostos, cuja aceitação depende de comparações com serviços semelhantes remunerados por emprêsas semelhantes da mesma região, além de se considerar a grandeza, a receita bruta e a rentabilidade da firma pagadora, a extensão da contribuição prestada para o seu êxito, a sua despesa total com a administração e o tempo dedicado pelo administrador. ${ }^{25}$

Critério semelhante é adotado na República Federal Alemã, mediante cotejo da remuneração paga ao diretor com pagamentos feitos pela própria ou outras firmas a terceiros por serviços semelhantes. ${ }^{26}$

Na área da sociedade fechada que, em princípio, mais atrai a atenção do fisco, dada a alegada tendência de aumentar o vulto

23 Washington, George Thomas e Rothschild, V. Henry. Compensating the Corporate Executive. Nova Iorque, The Ronald Press Company, 1951, p. 281 e seg.

24 WORLD TAX SERIES, Taxation in the United Kingdom. Boston, Toronto, Harvard Law School, 1957, p. 433.

25 World TAX SERIEs. Taxation in France. Chicago, Harvard Law School, 1966, p. 380 .

26 WORLD TAX SERIES. Taxation in the Federal Republic of Germany. Chicago, Harvard Law School, 1963, p. 341 e 395. 
da remuneração em detrimento dos lucros tributáveis, Washington e Rothschild focalizaram à parte a situação das pequenas emprêsas, merecedoras, segundo opinam, de tratamento mais brando. A confusão do administrador com o proprietário, coproprietário ou controlador que, de forma geral, suscita cuidados fiscais maiores em relação à sociedade fechada, no caso da pequena emprêsa assumiria condiçóes até para justificar a elevação dos limites de remuneração dêsses administradoresempresários modestos, num campo em que o remanescente após o pagamento das despesas operacionais e dos impostos é "ao mesmo tempo retribuição da habilidade do dirigente e do sucesso e da remuneração do capital", onde, enfim, o titular conta muito mais com a sua remuneração mensal do que com o que sobra, depois de consumida sua remuneração pessoal. Relatório publicado nos Estados Unidos da América demonstra como numerosas emprêsas pequenas continuam a operar, apesar de aparentemente deficitárias, pelo simples motivo de seus dirigentes estarem menos interessados em seus dividendos de acionistas do que na sua remuneração como administradores, embora essa por vêzes exceda os limites de pura compensação pelo trabalho para também, parcialmente, se transformar em remuneração do capital. ${ }^{27}$

Tal tolerância não deveria ser considerada fora de contexto de uma era de progressiva concentração das atividades econômicas, quando o poder público não pode desconhecer a sua responsabilidade na proteção, frente às grandes organizações em contínuo crescimento, das pequenas e médias emprêsas, inclusive no que diz respeito à conveniente dosagem da interferência fiscal.

\section{Uma Reformulação Necessária}

No Brasil, depois da existência efêmera do GEAMPE, criado com o declarado intuito de "atender à exigência de racional e prudente distribuição de cuidados e permanente assistência a todos os setores da economia, independente de sua grandeza, conhecido o fatalismo da impossibilidade de crescimento de uns

27 Washington, George Thomas e Rothschild, V. Henry. Op. cit., p. 281 e seg. 
pela atrofia de outros", ${ }^{28}$ surgiu, posteriormente, como medida concreta o FIPEME. Na esfera estritamente fiscal fêz-se notar, em benefício da pequena emprêsa, a criação pela Lei $n^{9} 4.506$, de 1964, das emprêsas individuais e a inclusão na declaração de rendimentos da pessoa física apenas dos lucros creditados ou pagos ao titular da emprêsa individual e não mais de todo o lucro apurado, distribuído ou não, como anteriormente exigido. Com referência à remuneração dos administradores, o fisco brasileiro, se não tem especialmente beneficiado, também não tem discriminado contra empreendedores individuais ou sociedades de pessoas, numa atitude que não deixa de ser positiva e contrária, com vantagem, a prática discriminatória de outros países; a orientação, neutra em face da organização jurídica das emprêsas, carece ainda de uma definição quanto à dimensão dos empreendimentos, para que possa corresponder à esperada proteção da pequena emprêsa.

Se a situação peculiar do dirigente da pequena emprêsa permite invocar motivos para a fixação de retiradas superiores aos níveis normais de remuneração do trabalho efetivamente prestado, nada justifica que a compensação do dirigente da média ou grande emprêsa seja inferior à remuneração adequada e justa da atividade exercida; se não deve ser superior, para não criar privilégios, também não deve inferiorizar o dirigente em relação aos demais colaboradores, para não suscitar injustiças, direta ou indiretamente, inclusive através do enquadramento das diferenças como excesso de retiradas, de modo a encarecer para as emprêsas os pagamentos efetuados aos seus dirigentes. Este aspecto é tanto mais significativo quanto, ao contrário do que sucede na pequena emprêsa, se verifica nas demais a crescente tendência de incluir nos órgãos de direção elementos não identificados com o contrôle acionário, porém qualificados para proporcionar ao empreendimento maior aperfeiçoamento técnico ou administrativo.

Publicou-se em 1964 minucioso estudo sôbre a atmosfera que envolve o empresário brasileiro, de autoria de Fernando Henrique Cardoso; o referido trabalho, apesar da reserva ainda demonstrada no tocante ao efetivo deslocamento, em escala na-

O Estado de São Paulo, 30/8/1960, p. 22. 
cional, do poder decisório do campo mais restrito dos diretoresproprietários em direção à área mais aberta dos administradores profissionais, ponderando que o "padrão familiar dos empreendimentos ainda é a norma", já admitia que a influéncia de "pressões dentro e fora do sistema industrial para alterá-lo" tornaria provável que "a administração das grandes emprêsas venha a ser controlada, em futuro não muito remoto, por um padrão misto em que à participação dos proprietários se acrescentará 0 aproveitamento de especialistas e profissionais. ${ }^{29}$

Desde então a procura e a oferta de administradores profissionais tem experimentado incremento notório. A composição mista dos colégios diretivos, prevista pelo citado autor e cada vez mais difundida, em virtude da própria necessidade de organização e racionalização das emprêsas, vem de dar origem a um projeto, inspirado pelo Banco Central, que, em suma, terá o objetivo de institucionalizá-la através da introdução do Conselho de Administração e da Diretoria Executiva das sociedades anônimas, o primeiro incumbido de compor a Diretoria Executiva mediante a contratação de "diretores executivos, que poderiam ser acionistas ou não, empregados ou não da firma, todos porém residentes no País" e de lhes fixar "remuneração e demais vantagens". ${ }^{30}$

O reconhecimento da evolução que ocorre na constituição dos quadros dirigentes, além de tôdas as outras considerações, teria de impor ao poder público a responsabilidade de conferir uma dimensão mais dinâmica a uma abordagem até agora mais restritiva ou estática; seria necessário, sobretudo, o rompimento com o tabu da fixação arbitrária das retiradas a fim de situálas como compensação efetiva e satisfatória de serviços prestados, igualando-as ou aproximando-as, tanto quanto possível, dos vencimentos percebidos por colaboradores de nível semethante, não investidos em cargo de diretoria.

Nem a vinculação da retirada com um elemento aleatório como o lucro, nem a volta ao status quo anterior assegurariam aquêle nivelamento ou aproximação, embora o esquema do período

29 CARDoso, Fernando Henrique. Empresário Industrial e Desenvolvimento Económico. São Paulo, Difusão Européia, 1964, p. 115 e seg.

30 Diário do Comércio. São Paulo, 14-16/2/1970, p. 13 
1957-1967 contivesse alguns pormenores úteis, subsidiàriamente, à montagem de um nôvo sistema voltado para tal objetivo; o critério comparativo individual, adotado em vários países, apesar de aproximar-se mais, não seria considerado oportuno, desde que a imposição de tetos gerais e uniformes, ao invés da adoção de critérios subjetivos baseados em comparaçóes e estimativas isoladas, parece, em princípio, ajustar-se melhor à realidade brasileira e às suas tendências de substituir o juízo ou arbítrio individual por normas gerais, o que afinal, além de atender a cogitaçóes de outra ordem, vem também ao encontro da insuficiência quantitativa do aparelho fiscalizador.

Entretanto, a introdução do critério comparativo em têrmos mais amplos, não restrito a situações individuaïs, ajustar-se-ia às tendências de uniformidade do tratamento fiscal brasileiro, sem deixar de oferecer suporte a uma avaliação mais racional do trabalho do dirigente; em vez de comparações em caráter individual, como vêm sendo feitas no exterior com vistas à razoabilidade, prevaleceria uma coleta de dados de ordem geral, retirados do mercado de trabalho especializado, ou então um salário profissional elaborado periodicamente pelos órgãos de classe representativos dos administradores de emprêsa profissionais.

O resultado obtido, devendo corresponder à remuneração média, seria reduzido ou aumentado para as emprêsas situadas, respectivamente, nas faixas abaixo ou acima da média; para essa delimitação de áreas, conforme a dimensão das emprêsas, é que se faria mister a inserção subsidiária do capital como elemento mais qualificado, tanto mais quanto, graças à correção periódica do átivo imobilizado e do ativo circulante, êsses ainda parcial, bem como à incorporação não onerosa dos lucros suspensos, ora transitória, o capital registrado jamais estêve tão próximo da expressão real do potencial da emprêsa; a introdução do critério do capital empregado, existente no início do ano-base, isto é, do capital realizado acrescido das reservas, tornaria a fórmula ainda mais completa. Por sua vez, a reintrodução do salário mínimo como ponto de referência do cálculo da retirada - expressa como múltiplo de salário mínimo - facilitaria o reajuste contínuo dos valôres uma vez atribuídos. 
Em estudo apresentado ao Congresso do Comércio Paulista, realizado em setembro de 1969, a Federação do Comércio do Estado de São Paulo focaliza como aspectos especiais da remuneração dos dirigentes e dos diretores de sociedades abertas e a dos empregados promovidos a diretores, geralmente sem dissolução do vínculo empregatício, propondo para os primeiros "o triplo da limitação da remuneração pro labore" e para os segundos "a aceitação de níveis de remuneração superiores ao fixado no caput ao artigo 16, quando o beneficiado, efetivamente, pertencer ao quadro de empregados há mais de dois anos..."; ${ }^{11}$ a introdução generalizada do critério comparativo tornaria dispensável a consideração à parte de tais aspectos, eis que, mantida a uniformidade básica, seria garantida, em princípio, a uns e outros remuneração comparável a atividades comparáveis, sem criar privilégios nem situações de inferioridade.

Uma apreciação realista não negaria, diante do predomínio ainda flagrante da emprêsa familiar, a procedência das cautelas de que se tem cercado o fisco para assegurar o relacionamento da retirada dedutível com o exercício efetivo e útil da atividade remunerada. A adoção do método comparativo, tendo por escopo remunerar adequadamente atividade efetivamente exercida, não invalidaria os dispositivos destinados ao bloqueio da evasão, existentes desde 1932 e reforçados em 1942 e 1964, todos, a seu turno, voltados para a efetividade da ação empresarial. $O$ esquema poderia ainda ser completado pelo revigoramento da limitação do número remunerável de diretores a menos de sete. conforme a dimensão da emprêsa, tal como já praticado no sistema anterior; a conjugação do dispositivo limitador com a abertura às emprêsas da faculdade de reservar a totalidade da remuneração colegial até a diretorias numèricamente inferiores aos limites estabelecidos, mediante a distribuição da soma entre os seus membros, viria a significar, ainda, um incentivo à redução do número de dirigentes, em benefício dos indispensáveis e atuantes, e um desestímulo à existencia de diretores fantasmas.

31 II Congresso do Comércio Paulista, Bertioga, 25 a 27/9/1969, tese apresentada pela Federação do Comércio do Estado de São Paulo. 


\section{QUADRO II}

Evolução das Remunerações Dedutiveis dos Dirigentes de Emprêsa

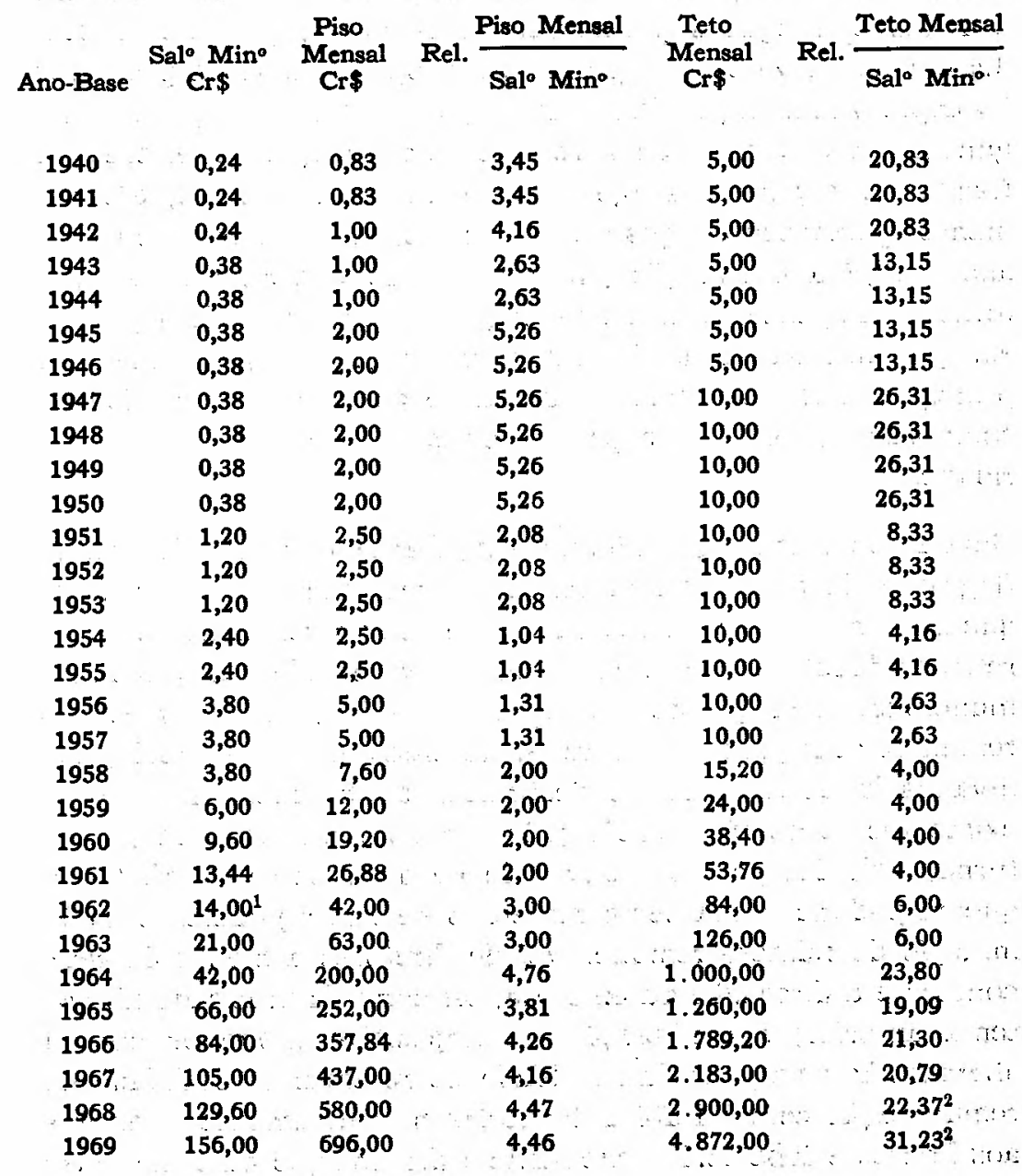

1 Salário mínimo de Cr $\$ 13,44$, transformádo em salario mínimo fiscal de $\mathrm{Cr} \$ 14,00$ :

2 :A aplicação desses tețos, aperentemente favoráveis, depende do volume de lucros; ao contrário do sistema anterior a 1968, sòmente há garantia do piso: 
Não resta dúvida de que a introdução do método comparativo poderá significar maior despesa dedutível e, portanto, menor tributação da pessoa jurídica, apesar de contribuir para incrementar e até acelerar a arrecadação por intermédio da pessoa física, inclusive através da retenção na fonte. $\mathrm{Na}$ abordagem de outra concessão, com reflexo sóbre a Receita, como a da dedutibilidade da Reserva para Manutenção do Capital de Giro Próprio, o fisco, depois de reconhecer a justiça da medida, acabou, por motivos de arrecadação, escalonando a sua aplicação definitiva, sem, no entanto, retroceder em relação ao princípio. Também no campo das retiradas dedutíveis, o primeiro passo seria o do reconhecimento de uma situação efetiva de desnível de vencimentos dedutíveis entre os administradores, ùnicamente em função da sua inclusão formal ou não nas diretorias oficialmente organizadas. A sugerida reparação dêsse desnível ou, ao menos, sua atenuação sucessiva, além de não ofender e, pelo contrário, se coadunar com os princípios de justiça fiscal, não deixará também de compatibilizar-se com os interêsses mais amplos do poder público, desde que, integrada numa política de estímulo à progressiva formação de quadros de administradores profissionais, se transforme como que num investimento realizado em benefício do próprio desenvolvimento econômico, num esfôrço, enfim, para conciliar a avaliação objetiva do seu trabalho com a imposição ao dirigente de crescentes responsabilidades econômicas e sociais.

O Instituto de Organização Racional do Trabalho da Guanabara, abreviadamente IDORT-GB, é uma sociedade civil de caráter científico, sem intuito de lucro, constituida de pessoas físicas e jurídicas que se interessam pelos problemas de racionalização do trabalho. O IDORT-GB tem sua sede à Praia de Botafogo, 186. 